\title{
PRINSIP FAIR USE TERHADAP COVER VERSION LAGU DALAM PERSPEKTIF PERLINDUNGAN HAK CIPTA (Perbandingan Antara Undang-Undang Hak Cipta Indonesia Dengan Amerika Serikat)
}

\author{
Margaritha Rami Ndoen', Hesti Monika²
}

\begin{abstract}
Abstrak
Prinsip Fair Use merupakan bentuk pembatasan yang memperbolehkan pihak lain untuk menggunakan sebuah karya tanpa meminta izin kepada pencipta dalam batas batas tertentu. Dalam Undang-Undang Nomor 28 tahun 2014 tentang Hak Cipta juga menerapkan prinsip fair use dengan berbagai batasan dan juga kategorinya. Jika dikaitkan dengan tindakan cover version sebuah lagu, maka prinsip ini bisa saja digunakan selama hal tersebut memenuhi unsur yang terdapat dalam Undang-Undang Hak Cipta. Hanya saja, fenomena tersebut harus dilihat dalam kasus per kasus sesuai dengan kategori dan keperluan serta tujuan dari tindakan cover version. Peraturan perundang-undangan yang ada pun belum mencakup hal tersebut, sehingga masih menimbulkan pertanyaan, apakah tindakan ini merupakan pelanggaran Hak Cipta atau bukan. Penulisan ini juga melakukan perbandingan dengan yang terjadi di Amerika Serikat berdasaran US Copyright Act 1976, sekaligus melihat persamaan dan perbedaannya dengan Undang-Undang Hak Cipta. Di akhir penulisan, penulis berkesimpulan bahwa tindakan cover version terhadap sebuah lagu selama tidak memenuhi unsur yang termuat dalam Pasal 44 Undang-Undang Hak Cipta adalah merupakan pelanggaran Hak Cipta dan tidak dapat dikatakan sebagai penerapan prinsip fair use.
\end{abstract}

Kata Kunci : Fair Use, Hak Cipta, Cover Version Lagu

\section{PENDAHULUAN}

\subsection{Latar Belakang}

Perkembangan media sosial dapat dikatakan bagai pisau bermata dua, di satu sisi memberikan kemudahan berkomunikasi bagi setiap orang, menjadi sarana untuk mengembangkan diri melalui karya seni sekaligus memberikan kontribusi bagi peningkatan kesejahteraan dan peradaban manusia. Namun, di sisi lain perkembangan media sosial dapat menjadi sarana untuk memanfaatkan hasil karya orang lain tanpa meminta izin pemegang hak cipta dalam bentuk mengambil seluruh atau sebagian, memodifikasi hasil karya orang lain, yang dalam hal ini berbentuk karya seni lagu / cover version lagu.

Salah satu media yang seringkali digunakan untuk kegiatan semacam ini adalah Video Sharing Website YouTube yang sangat terkenal dan menjadi media paling ampuh untuk mereguk sebuah popularitas. Berbagai fenomena di tanah air menunjukkan bahwa penggunaan media sosial menjadi sarana untuk mencapai popularitas hanya dengan menggunakan lagu ciptaan orang lain, baik dari dalam negeri maupun luar negeri.

Di Indonesia proses hukum terhadap tindakan cover version lagu yang disebarkan melalui jejaring media internet belum pernah ditemukan, seperti halnya di luar negeri. Dalam Pasal 1 Ayat (1) Undang-Undang Nomor 28 Tahun 2014 tentang Hak Cipta yang menyatakan bahwa Hak Cipta adalah hak eksklusif pencipta yang timbul secara otomatis berdasarkan prinsip deklaratif setelah suatu ciptaan diwujudkan dalam bentuk nyata tanpa mengurangi pembatasan sesuai dengan ketentuan peraturan perundang-undangan. Hak eksklusif dalam hal ini adalah bahwa hanya pencipta dan pemegang hak sajalah yang bebas melaksanakan hak cipta tersebut, sementara orang lain atau pihak lain dilarang melaksanakan hak cipta tersebut tanpa persetujuan pemegang hak cipta.

Namun, hak eksklusif yang dimiliki oleh pemegang hak cipta atau pencipta tidaklah secara mutlak dimiliki penuh karena adanya suatu batasan, dimana seseorang yang ingin menggunakan atau memanfaatkan hasil karya dari pencipta tidak memerlukan izin untuk menggunakannya selama tidak merugikan kepentingan yang wajar atas penggunaannya. Batasan-batasan ini dikenal dengan istilah prinsip penggunaan yang wajar (fair use). Prinsip ini memiliki pengertian apabila seseorang yang ingin

\footnotetext{
${ }^{1}$ Dosen Fakultas Hukum Universitas Kristen Indonesia Paulus

${ }^{2}$ Mahasiswa Fakultas Hukum Universitas Kristen Indonesia Paulus Makassar
} 
mengambil karya seseorang dalam hal kepentingan pendidikan, penelitian, dan karya ilmiah. sebagimana yang diatur dalam Pasal 44 Ayat (1) huruf a Undang-Undang Nomor 28 Tahun 2014 tentang Hak Cipta.

Doktrin fair use di Amerika Serikat tidak hanya berusaha melindungi pencipta sebagai bagian atas hak ekonomi mereka tetapi juga memberikan kesempatan pengamanan untuk kepentingan umum yang lebih luas, tidak terbatas hanya pada pengguna atau pemakai karya cipta yang bersangkutan. Di Amerika Serikat, penggunaan materi bahan hak cipta diperbolehkan tanpa adanya izin dari pencipta dalam keadaan sosial tertentu. Undang-Undang Hak Cipta Amerika Serikat menggabungkan hak cipta dengan hak ekonomi sekaligus. Hal ini merupakan komitmen Amerika Serikat untuk melindungi hak cipta dan mencegah pelanggaran terhadap hak cipta.

Prinsip Fair Use dalam Undang-Undang Hak Cipta tidak mengatur mengenai penggunaan yang wajar terhadap karya seni musik, sehingga norma hukum mengenai fair use itu sendiri menjadi sangat kurang, hal ini disebabkan karena adanya kekosongan hukum mengenai prinsip fair use dalam karya seni musik. Hal ini seringkali mengakibatkan banyak karya musik / lagu yang dengan mudah dimodifikasi oleh orang lain dan justru menimbulkan kerugian bagi pencipta atau pemegang hak cipta.

\subsection{Permasalahan}

Berdasarkan latar belakang tersebut, ditemukan permasalahan yaitu

1. Apakah tindakan cover version terhadap lagu merupakan pelanggaran terhadap Undang-Undang Hak Cipta jika dikaitkan dengan prinsip Fair Use?

2. Bagaimana perbandingan pengaturan hukum terkait dengan prinsip Fair Use menurut UndangUndang Hak Cipta No. 28 Tahun 2014 dengan US Copyright Act 1976 ?

\subsection{Tujuan Penelitian}

1. Mengetahui apakah tindakan cover version terhadap lagu merupakan pelanggaran terhadap UndangUndang Hak Cipta jika dikaitkan dengan prinsip Fair Use.

2. Mengetahui perbandingan pengaturan hukum terkait dengan prinsip Fair Use menurut UndangUndang Hak Cipta No. 28 Tahun 2014 dengan US Copyright Act 1976

\section{LANDASAN TEORI}

\subsection{Definisi Fair Use}

Fair use adalah pembatasan yang beralasan mengenai penggunaan karya cipta tanpa ijin pencipta, seperti mengutip dari buku dalam review buku atau menggunakan bagian dari buku tersebut untuk kepentingan parody. Fair use juga didefinisikan sebagai prinsip hak cipta berdasarkan kepercayaan bahwa publik berhak menggunakan secara bebas porsi materi karya cipta untuk tujuan komentar dan kritik. Berdasarkan definisi tersebut, fair use adalah doktrin atau prinsip yang memperbolehkan pihak lain untuk menggunakan kreasi hak cipta tertentu untuk kepentingan atau tujuan yang spesifik. Menurut Joseph Turow, fair use adalah ketentuan dimana seseorang atau sebuah perusahaan dapat menggunakan sebagian kecil karya yang tercatat hak cipta tanpa harus izin kepada si pencipta karya. Lebih lanjut, Prof. Eddy Damian berpendapat bahwa dengan adanya pengaturan hukum penggunaan yang wajar (fair use), hukum hak cipta memperkenankan seseorang yang dalam hal ini pihak ketiga untuk menggunakan atau mengeksploitasi ciptaan tanpa perlu izin dari pencipta, asalkan dalam batas-batas yang diperkenankan.

Sebagai contoh, membuat konteks dengan menggunakan bagian dari buku tanpa mencari otorisasi dari pemegang hak cipta. Jika pemegang hak cipta keberatan atas hal tersebut maka kemudian pemegang hak cipta yang bersangkutan dapat menggugat pemakai karya cipta tanpa ijin tersebut sebagai pelanggaran hak cipta dan pengguna dapat menggunakan pembelaan affirmative (persetujuan) akan hal tersebut sebagai sebuah fair use.

Pada media internet setiap orang dapat menampilkan kreatifitasnya tetapi terdapat kebebasan oleh pihak lain pula untuk menggunakan kreasi tersebut. Kebebasan ini umum disebut sebagai public freedom access atau kebebasan akses publik. Perdebatan pertama mengenai perlindungan hak cipta dan kebebasan akses publik dimulai secara online pada beberapa blog dan website. Isu hukum yang paling sering muncul adalah tindakan caching dan archiving website. Tindakan caching dan archiving adalah bentuk baru dari fair use. Bentuk baru ini terlihat serupa dengan tindakan copying dan pasting, 
tetapi lebih mudah secara elektronik dan memiliki dampak peningkatan penggunaan dan jumlah dari materi yang di copy atau disalin.

\subsection{Prinsip Fair Use Dalam Undang-Undang Nomor 28 Tahun 2014 Tentang Hak Cipta}

Hak pemilik atas karya cipta tidak serta merta menjadikan seseorang untuk monopoli dan memparkaya diri sendiri atas hak ekonomi yang sudah diperolehnya untuk menyeimbangkan hak pemilik dengan kepentingan masyarakat, maka UUHC mengizinkan penggunaan ciptaan-ciptaan tertentu tanpa perlu izin pencipta. Pengaturan mengenai doktrin fair use di Indonesia terdapat pada bagian IV Pembatasan Hak Cipta Pasal 43 sampai Pasal 51 UndangUndang Hak Cipta Nomor 28 Tahun 2014.

Berdasarkan Pasal 44, menggunakan kreasi tertentu tidak dinyatakan sebagai sebuah pelanggaran terhadap hak cipta selama sumber kreasi tersebut disebutkan secara jelas dan hal tersebut hanya digunakan terbatas untuk tujuan yang tidak menghasilkan profit atau komersial, termasuk kegiatan sosial, seperti pendidikan dan pengetahuan, penelitian dan pengembangan. Pasal 44 menyatakan bahwa :

1. Penggunaan, pengambilan, penggandaan, dan/atau pengubahan suatu piptaan dan/atau produk Hak Terkait secara seluruh atau sebagian yang substansial tidak dianggap sebagai pelanggaran Hak Cipta jika sumbernya disebutkan atau dicantumkan secara lengkap untuk keperluan :

a. pendidikan, penelitian, penulisan karya ilmiah, penyusunan laporan, penulisan kritik atau tinjauan suatu masalah dengan tidak merugikan kepentingan yang wajar dari Pencipta atau Pemegang Hak Cipta;

b. keamanan serta penyelenggaraan pemerintahan, legislatif, dan peradilan;

c. ceramah yang hanya untuk tujuan pendidikan dan ilmu pengetahuan; atau

d. pertunjukan atau pementasan yang tidak dipungut bayaran dengan ketentuan tidak merugikan kepentingan yang wajar dari Pencipta.

2. Fasilitasi akses atas suatu Ciptaan untuk penyandang tuna netra, penyandang kerusakan penglihatan atau keterbatasan dalam membaca, dan/atau pengguna huruf braille, buku audio, atau sarana lainnya, tidak dianggap sebagai pelanggaran Hak Cipta jika sumbernya disebutkan atau dicantumkan secara lengkap, kecuali bersifat komersial.

3. Dalam hal Ciptaan berupa karya arsitektur, pengubahan sebagaimana dimaksud pada ayat (1) tidak dianggap sebagai pelanggaran Hak Cipta jika dilakukan berdasarkan pertimbangan pelaksanaan teknis.

Penerapan prinsip fair use di Indonesia hanya berlaku pada ciptaan-ciptaan yang memiliki perlindungan hak cipta karena prinsip fair use adalah doktrin yang memperbolehkan penggunaan suatu ciptaan yang dilindungi hak cipta tanpa izin atau pemegang hak cipta. Dengan demikian, ada beberapa ciptaan dalam hukum hak cipta Indonesia yang tidak dapat memberlakukan prinsip fair use, yaitu :

1. Ciptaan berdasarkan Pasal 13 Undang-Undang Hak Cipta, yaitu hasil-hasil rapat terbuka lembaga Negara, Peraturan Perundang-undangan, Pidato Kenegaraan atau pidato pejabat pemerintah, putusan pengadilan atau penetapan hakim, keputusan badan arbitrasi atau badan-badan sejenis lainnya.

2. Ciptaan yang telah habis masa perlindungannya.

3. Ciptaan yang tidak memenuhi unsur-unsur dalam Pasal 1 angka 2 dan Pasal 1 angka 3 UndangUndang Hak Cipta.

\subsection{Pengaturan Fair Use di Amerika Serikat Menurut Copyright Act. 1976}

Prinsip fair use dalam United States Copyright Act 1976 terdapat dalam Pasal 107. Dalam pasal tersebut menjelaskan bahwa penggunaan yang wajar dari sebuah karya hak cipta, termasuk penggunaan tersebut oleh reproduksi dalam salinan phonerecord atau oleh orang untuk tujuan seperti kritik, komentar, laporan berita, mengajar (termasuk beberapa salinan untuk penggunaan di dalam kelas), pendidikan, atau penelitian, bukan merupakan pelanggaran hak cipta.

Untuk menentukan apakah penggunaan tersebut merupkan penggunaan yang wajar harus dipertimbangkan menggunakan 4 (empat) faktor:

1. Tujuan dan karakter penggunaan, termasuk apakah penggunaan semacam itu memiliki sifat komersial atau untuk tujuan pendidikan nonprofit.

2. Sifat dari karya cipta yang dilindungi. 
3. Jumlah dan bagian penting yang digunakan dari keseluruhan ciptaan.

4. Efek dari penggunaan terhadap pasar atau terhadap nilai dari karya ciptaan yang digunakan.

Dalam menentukan suatu penggunaan yang wajar, hakim pengadilan Amerika Serikat akan mengelaborasi fakta dengan empat faktor tersebut. Keempat faktor tersebut harus dipertimbangkan secara keseluruhan dalam suatu perkara. Berdasarkan praktek pengadilan Amerika Serikat, faktor keempat merupakan yang terpenting.

Martine Courant Rife menyatakan bahwa prinsip fair use menjadi tidak relevan ketika hak cipta tidak melindungi suatu ciptaan. Menurutnya, ada beberapa beberapa hal yang membuat prinsip fair use tidak berlaku pada suatu ciptaan, yaitu :

1. Ciptaan tersebut sudah berada dalam domain publik, artinya masa perlindungan hak cipta sudah habis.

2. Ciptaan yang diciptakan oleh Pemerintah Amerika Serikat, seperti Putusan Pengadilan, Statuta, dan peraturan-peraturan.

3. Ciptaan yang tidak orisinal.

4. Penggunaan ciptaan yang de minimis, artinya penggunaan ciptaan tersebut tidak cukup melibatkan kuantitas dari ciptaan yang disalin untuk membuat adanya kesamaan substansial.

5. Penggunaan ciptaan yang seizin penciptanya.

Selain lima ciptaan tersebut, Copyright Act juga tidak mengatur ciptaan yang melanggar hukum. Hanya saja dapat dilihat dalam praktek peradilan di Amerika Serikat, seperti Bullard v. Esper mengenai kandungan bersifat cabul, mengenai frasa dalam lagu Hottest Thing You Ever Seen yang memiliki makna tidak bermoral, dan sebagainya. Terhadap ciptaan yang melanggar hukum ini, Paul Goldstein menyatakan bahwa pertimbangan untuk menentukan suatu suatu muatan yang melanggar hukum ini pada intinya terdapat pada hukum negara bagian dan nilai-nilai yang dianut masyarakat setempat.

\section{METODE PENELITIAN}

Metode yang digunakan dalam penelitian ini adalah pendekatan Perundang-Undangan (statue approach), pendekatan perbandingan (comparative approach) dan pendekatan konsep (conseptual approach) dan menggunakan bahan hukum primer, yaitu bahan hukum terkait dengan konvensi internasional HKI yang diratifikasi Indonesia, United State Copyright Act 1976 dan Undang-Undang Nomor 28 Tahun 2014 Tentang Hak Cipta, serta bahan hukum sekunder, yaitu bahan hukum yang memberikan petunjuk dan penjelasan terhadap bahan hukum primer yang terdiri dari buku-buku, literature, makalah, artikel dari internet dan karya ilmiah lainnya yang berhubungan dengan penelitian. Data yang diperoleh dianalisis secara deduktif, yakni mencari solusi sebagai kesimpulan tentang bagaimana konsep fair use dalam tindakan cover version sebuah lagu.

\section{HASIL DAN PEMBAHASAN}

\subsection{Tindakan Cover Version Lagu Terkait Prinsip Fair Use}

Dewasa ini, perkembangan ilmu pengetahuan dan teknologi informasi menjadi sarana yang sangat populer di kalangan masyarakat untuk membuat dan mempublikasikan karya seni yang dihasilkan. Salah satu bentuk karya seni yang marak dipublikasikan melalui media internet / media sosial adalah lagu. Publikasi ini meliputi lagu yang merupakan produk atau hasil karya sendiri, maupun memodifikasi atau menyanyikan ulang lagu yang diciptakan oleh orang lain / cover version. Di Indonesia misalnya, begitu banyak fenomena cover version terhadap lagu dari artis seperti Chrisye, Dewa 19, Jikustik, Peterpan, D'Masiv, dan sebagainya yang dilakukan oleh pihak lain denga versi mereka sendiri. Fenomena cover version lagu ini tidak hanya menjadi trend di dalam negeri, melainkan juga di luar negeri.

Lagu merupakan salah satu bentuk ciptaan yang dilindungi berdasarkan Pasal 40 ayat (1) huruf d Undang-Undang Nomor 28 Tahun 2014 tentang Hak Cipta. Bila menggunakan pendekatan UndangUndang Hak Cipta, apakah tindakan cover version lagu yang diumumkan di media sosial tanpa adanya izin dari pencipta maupun pemegang hak terkait termasuk ke dalam penggunaan yang wajar / fair use atau termasuk dalam pelanggaran hak cipta dapat dilihat dari pembatasan dan pengecualian terhadap karya seni musik yang diatur dalam Pasal 43 dan Pasal 44. Menurut Pasal 43, menyanyikan ulang lagu yang diumumkan di media sosial dapat dikatakan sebagai penggunaan yang wajar apabila karya cipta tersebut merupakan tindakan memperbanyak dan/atau pengumuman lagu kebangsaan menurut sifatnya 
yang asli. Jadi tidak ada alternatif lain selain menurut sifatnya yang asli dan tidak boleh diubah. Hal ini tidak dianggap sebagai pelanggaran hak cipta. Terkait dengan penyebarluasan konten hak cipta melalui media teknologi informasi dan komunikasi, Pasal 43 menyatakan bahwa pembuatan dan penyebarluasan konten Hak Cipta melalui media teknologi informasi dan komunikasi yang

bersifat tidak komersial dan/atau menguntungkan Pencipta atau pihak terkait, atau Pencipta tersebut menyatakan tidak keberatan atas pembuatan dan penyebarluasan tersebut bukanlah tindakan pelanggaran Hak Cipta.

Undang-Undang Hak Cipta memperbolehkan penggunaan ciptaan lain yang dalam hal ini adalah lagu untuk kepentingan pendidikan, penelitian, penulisan karya ilmiah, penyusunan laporan, penulisan kritik atas tinjauan suatu masalah dalam arti tidak merugikan kepentingan yang wajar dari pencipta, dengan syarat bahwa sumbernya harus disebutkan atau dicantumkan, sebagaimana yang ditentukan dalam Pasal 44 ayat (1) Undang-Undang Hak Cipta. Contohnya adalah seorang guru musik yang memanfaatkan karya orang lain untuk dinyanyikan ulang di depan muridnya agar murid tersebut mengerti tentang musik, dalam arti bahwa tindakan seorang guru tersebut hanya ditujukan untuk muridnya saja dan tidak dimanfaatkan untuk kepentingan komersial.

Undang-Undang Hak Cipta juga memberikan batasan dengan syarat terhadap perbanyakan suatu ciptaan dalam bidang ilmu, seni dan sasta dalam huruf braile guna keperluan para tuna netra, di mana terlihat adanya fungsi sosial yang lebih konkret. Terhadap karya seni musik / lagu terkait ciptaan yang penciptanya tidak diketahui yakni terhadap hak cipta atas folklor dan hasil kebudayaan rakyat yang di mana negara sebagai pemegang hak cipta atas karya peninggalan prasejarah dan sejarah, maka untuk mengumukan atau memperbanyak ciptaan tersebut, selain orang yang bukan warga negara Indonesia harus terlebih dahulu mendapatkan izin dari instansi yang terkait dalam masalah tersebut. Dalam arti bahwa hanya warga negara Indonesia saja yang diperbolehkan melakukan tindakan pengumuman atau perbanyakan baik untuk kepentingan komersial maupun non-komersial tidak perlu mendapatkan izin dari instansi yang berwenang.

Selain ketentuan-ketentuan diatas mengenai fair use terhadap penggunaan karya cipta orang lain khususnya lagu yang diumumkan melalui media teknologi sebagaimana yang marak terjadi saat ini, tidak diatur dalam peraturan perundang-undangan mengenai penggunaan yang wajar atas ciptaan tersebut. Untuk melihat fenomena cover version lagu, apakah termasuk pelanggaran hak cipta atau tidak, dapat dilakukan dengan melihat unsur-unsur yang ada dalam Pasal 44. Unsur-unsur tersebut terkait dengan keperluan melakukan cover version lagu, penyebutan sumber secara lengkap, tidak merugikan kepentingan yang wajar dari pencipta, dan bukan untuk kepentingan komersial. Terkait penyebarluasan melalui media sosial, juga perlu untuk diperhatikan unsur-unsur yang termuat dalam ketentuan Pasal 43. Dengan kata lain, Menyanyikan ulang lagu milik orang lain tanpa adanya persetujuan atau izin dari pencipta hal tersebut termasuk ke dalam pelanggaran hak cipta, sehingga apabila seseorang ingin mengumumkan karya cipta milik orang lain baik yang telah dimodifikasi, aransemen, dan/atau dinyanyikan ulang harus mendapatkan izin dari pencipta atau pemegang hak terkait. Selama tindakan cover version sebuah lagu tidak memenuhi unsur yang terdapat dalam Pasal 43 dan Pasal 44, hal tersebut merupakan pelanggaran terhadap Hak Cipta.

Dalam derajat kepastian hukum untuk mengetahui penggunaan yang berbasis fair use, tidak ditemukan dalam undang-undang terhadap kualifikasi fair use, namun untuk mengetahui penggunaan atas ciptaan yang berbasis fair use dapat merujuk kepada putusan pengadilan/hakim, yakni dapat ditemukan apabila ada kasus yang berpekara terkait fair use

Menurut penulis, fenomena cover version yang selama ini marak terjadi sebagian besar tidak memenuhi seluruh unsur yang ada dalam Pasal 43 ataupun Pasal 44 sebagai bentuk penerapan prinsip fair use. Sebagian besar tindakan cover version yang dilakukan hanya mencantumkan sumber / pencipta / pemegang hak cipta sebuah lagu. Memang beberapa diantaranya melakukan tindakan cover version untuk kepentingan pribadi semata. Akan tetapi perlu dilihat apakah tindakan tersebut menimbulkan kerugian terhadap kepentingan yang wajar dari pencipta / pemegang hak cipta. Bahkan terdapat pula tindakan cover version lagu yang tidak menyebutkan sumber dan melakukan tindakan tersebut untuk kepentingan komersial. Hal ini jelas merupakan pelanggaran terhadap Hak Cipta.

\subsection{Studi Perbandingan Dengan US Copyright Law di Amerika Serikat}

Bila mengacu pada US Copyright Act 1976 dalam Pasal 107 untuk menentukan apakah menyanyikan ulang lagu yang diumumkan di media sosial termasuk kedalam pelanggaran atau 
termasuk kedalam fair use, yakni menguji menggunakan beberapa faktor. Faktor pertama yaitu tujuan dan karakter penggunaan, apakah digunakan untuk kepentingan komersial atau digunakan untuk kepentingan non-komersial. Apabila digunakan untuk kepentingan non-komersial maka dapat dikategorikan sebagai fair use namun apabila untuk kepentingan komersial maka harus mendapatkan lisensi dari pencipta atau pemegang hak cipta. Pengadilan biasanya berfokus pada apakah penggunaan tersebut bersifat "transformatif". Artinya, apakah penggunaan menambahkan ekspresi atau makna baru pada materi asli, atau hanya salinan dari aslinya. Penggunaan yang dilakukan secara komersial tidak dianggap sebagai penggunaan wajar, meskipun merubah dalam arti memodifikasi video dapat dilakukan dan masih ada manfaat yang dapat diambil dari penggunaan wajar. Sebagai tambahan, untuk mengevaluasi efek dari faktor pada fair use dengan tekhnologi, pengadilan harus mengevaluasi karakter komersial dan keaslian perubahan bentuknya.

Faktor kedua yaitu sifat dari karya cipta yang dilindungi. Sifat dasar dari ciptaan terkadang diukur melalui kreativitas dan originalitas yang diinvestasikan oleh pencipta. Apabila pengguna hanya menyalin karya ciptaan tersebut sebanyak yang dibutuhkan untuk kepentingannya, maka tindakan dalam menyanyikan ulang lagu yang diumumkan di jejaring media sosial dianggap sebagai penggunaan yang wajar. Menggunakan materi dari karya yang sebagian besar merupakan kenyataan lebih dapat dianggap sebagai penggunaan wajar dibandingkan dengan menggunakan karya yang benar-benar fiksi.

Faktor ketiga yaitu jumlah dan porsi substansi isi yang digunakan, prinsip umum dari pengujian atas proporsi atau bagian yang diambil dari Ciptaan yaitu semakin banyak bagian yang diambil, semakin besar kemungkinan terjadinya pelanggaran. Terlebih dahulu harus didefinisikan istilah "banyak" dalam konteks ini. Istilah "banyak" dalam konteks ini dapat didefinisikan dengan substansi proporsional atau kualitas yang diambil. Artinya, pengambilan bagian yang substansial atau pokok dari ciptaan yang dianggap sebagai pelanggaran. Penilaian secara kualitatif dan kuantitatif perlu dilakukan untuk menentukan apakah termasuk kedalam fair use atau pelanggaran.

Pemeriksaan secara kuantitatif dilakukan dengan memperhatikan bagian yang diambil terhadap ciptaan asli. Terhadap karya seni musik, lirik dan video musik pengambilan bagian terhadap fair use dilakukan maksimal 10\% dari karya cipta tersebut tetapi tidak lebih dari 30 detik. Meminjam sebagian kecil materi dari karya aslinya lebih dapat dianggap sebagai penggunaan wajar dibandingkan dengan meminjam sebagian besar. Namun, bahkan pengambilan sejumlah kecil dapat membatalkan penggunaan wajar dalam beberapa keadaan jika yang digunakan merupakan "inti" dari karya.

Faktor terakhir yaitu efek dari penggunaan terhadap pasar atau terhadap nilai dari karya ciptaan yang digunakan yakni dampak yang akan ditimbulkan yang dapat merugikan hak cipta. Penggunaan yang merugikan kemampuan pemilik hak cipta untuk mendapatkan keuntungan dari karya aslinya cenderung tidak dianggap sebagai penggunaan wajar. Dalam beberapa kondisi, bagian kecil dari suatu ciptaan dapat menjadi bagian pokok dari nilai ekonomi atas ciptaan tersebut. Penggunaan bagian kecil yang secara ekonomis merupakan bagian pokok ini memperbesar kemungkinan bahwa penggunaan yang dimaksud akan dinyatakan sebagai bukan penggunaan yang wajar. Namun, harus dicatat bahwa akibat ekonomi terhadap pasar dari ciptaan bukan merupakan faktor utama dari pemeriksaan penggunaan yang wajar (fair use), meskipun faktor ini merupakan sering digunakan sebagai kunci dalam menentukan penggunaan yang wajar. Untuk menentukan akibat dari fair use yang dapat merugikan kepentingan pencipta yakni terhadap dampak keuangan, dapat dilakukan dengan audit oleh akuntan publik untuk menganalisis dampak penggunaan karya tersebut dapat merugikan penjualan atau nilai ekonomi dari ciptaan karya yang digunakan oleh pengguna.

Adanya fenomena publikasi hasil ciptaan melalui elektronik/online telah menjadikan hasil cipta seseorang dengan mudah digunakan atau diunduh oleh semua orang tanpa seijin pencipta. Pada tahun 2001 telah lahir sebuah organisasi nirlaba (nonprofit oriented) di Amerika Serikat yang yang fokus memberikan lisensi kepada masyarakat pengguna jasa elektronis / online untuk dapat menggunakan menggunakan, mendistribusikan karya kreatif tanpa mengurangi substansi hak cipta seseorang secara gratis.

Organisasi tersebut bernama "Creative Commons". Organisasi ini akan memberikan standar kepada pemegang hak cipta, sehingga pencipta dapat memberikan ijin kepada pihak lain yang ingin menggunakan hasil ciptaannya. Melalui lisensi yang dibuat oleh "Creative Commons", maka diharapkan penggunaan hak cipta seseorang dapat bermanfaat bagi banyak orang dan digunakan secara legal (tidak melanggar hukum). 
Creative Commons ingin membuat sebuah free cultural works atau budaya berbagi karya cipta/ide kreatif yang dibuat oleh pencipta sehingga bisa bermanfaat bagi orang lain. Pada saat ini lisensi "Creative Commons" telah digunakan oleh para webmaster, blogger, dan jurnalis secara gratis (termasuk publikasi jurnal ilmiah). Creative Commons memberikan lisensi tak berbayar dan menyediakan banyak bentuk karya cipta yaitu melalui teks, gambar (ilustrasi, desain, foto), audio, audio visual, software dan jenis konten yang lainnya.

\section{KESIMPULAN DAN SARAN}

\subsection{Kesimpulan}

1. Tindakan cover version terhadap sebuah lagu yang tidak memenuhi unsur sebagaimana yang diatur dalam Pasal 43 dan Pasal 44 Undang-Undang Nomor 28 Tahun 2014 bukan merupakan penerapan atas prinsip fair use dan merupakan pelanggaran Hak Cipta. Unsur-unsur yang harus terpenuhi untuk dapat dikatakan sebagai tindakan fair use menurut aturan ini adalah tindakan yang dilakukan untuk keperluan pendidikan, kritik, penelitian dan pengetahuan, penyebutan sumber / pencipta / pemegang hak cipta dan tidak merugikan kepentingan yang wajar dari pencipta, serta bukan untuk keperluan komersial.

2. Perbandingan pengaturan terkait prinsip fair use antara Undang-Undang Hak Cipta dengan Copyright Law di Amerika Serikat adalah keduanya memiliki persamaan dan perbedaan. Kesamaannya adalah dalam hal adanya kategori dan tujuan dari peraturan mengenai fair use itu sendiri. Baik Amerika Serikat dan Indonesia mengatur fair use untuk kepentingan pendidikan, kritik, penelitian dan pengetahuan. Peraturan fair use yang memperbolehkan penggunaan karya cipta untuk pendidikan, kritik, penelitian dan pengetahuan akan mendorong dan meningkatkan penemuan dan perkembangan pengetahuan dan penelitian. Sedangkan perbedaannya pada Copyright selain kategori fair use, terdapat pula empat faktor untuk menetukan penggunaan suatu karya (lagu) berbasis fair use yakni, tujuan dan karakter penggunaan, sifat dari karya cipta yang dilindungi, jumlah dan bagian penting yang digunakan dari keseluruhan ciptaan, serta efek dari penggunaan yang dapat merugikan pencipta atau pemegang hak cipta. Faktor dan indikator seperti inilah yang tidak diatur dalam Undang-Undang Hak Cipta.

\subsection{Saran}

1. Penerapan prinsip fair use dalam Undang-Undang Nomor 28 Tahun 2014 perlu direvisi dan disesuaikan dengan perkembangan teknologi informasi komunikasi dan fenomena sosial masyarakat yang terjadi saat ini. Dalam hal ini, penerapan prinsip fair use dapat dilengkapi dengan peraturan tambahan yang lebih komprehensif dan di dalamnya juga termuat faktor-faktor yang merupakan pertimbangan dalam menerapkan prinsip fair use dalam suatu karya.

2. Penerapan sanksi yang tegas terhadap pelanggaran Hak Cipta, khususnya karya seni berupa lagu. Diperlukan pengaturan pidana apabila terjadi pelanggaran terhadap karya seni musik yang merugikan pencipta aslinya juga terutama jumlah hukuman denda. Hukuman denda perlu memperhatikan keseimbangan kepentingan dari penggugat dan kerugian disebabkan oleh tindakan pelanggaran hak cipta dari tergugat, untuk meminimalisir tindakan pelanggaran di internet terutama di jejaring media sosial yang saat ini marak terjadi.

\section{DAFTAR PUSTAKA}

Bakrie Muhammad, 2012, Hak Milik Intelektual, Sinar Grafika : Jakarta Eddy Damian, 2005, Hukum Hak Cipta, Edisi Kedua. Cetakan Ke-3, Alumni : Bandung Isnaeni Yusran, 2009, Hak Cipta dan Tantangannya di Era Cyber Space, Ghalia Indonesia : Bogor Khoirul Hidayah, 2017, Hukum Kekayaan Intelektual, Setara Press : Malang

Roger E. Schechter and John R. Thomas, 2003, Intellectual Property : the Law of Copyrights, Patens, and Trademarks, West Group : St. Paul

Tomy Suryo Utomo, 2010, Hak Kekayaan Intelektual Di Era Global, Graha Ilmu : Yogyakarta,

Undang-Undang Nomor 28 Tahun 2014 tentang Hak Cipta

US Copyright Act 1976

Paul Goldstain, Copyright, Volume I, Canada, Little Brown \& Company, 1989

Thomson West, 2001, Black Law Dictionary Third Pocket Edition 279 
Martine Courant Rife, The Fair Use Doctrine : History, Application and Implications for (New Media) Eriting Teachers, Department of Communication, Lansing Community College, USA, 2007, www.msu.edu/ mcgrat71/Writing/Fair_Use_Rife 